\title{
INDIGNIDADE, DESERDAÇÃO \\ E SEUS EFEITOS
}

\author{
Ceres Linck dos Santos
}

\section{INTRODUÇÃO}

A base do direito sucessório é a transmissão imediata da herança do falecido aos herdeiros legítimos e testamentários, como se extrai expressamente da dicção do art.1.784 do Código Civil, in verbis: "Art.1.784. Aberta a sucessão, a herança transmite-se, desde logo, aos herdeiros e testamentários".

Trata-se da consumação do princípio da Saisine. Todavia, tal transmissão está condicionada à legitimação sucessória. Assim, é necessário que o herdeiro, além de ser vocacionado à herança, seja legítimo e não excluído da sucessão, ou melhor, que possua qualidade de suceder na herança dei- xada pelo falecido. A doutrina costuma denominar esse atributo de capacidade sucessória. Importante deixar claro que, quando nos referimos à capacidade sucessória, estamos falando de legitimidade, como abordado no Código Civil em seus arts. 1.787, 1.798 e 1.802 .

Essa qualidade não se confunde com a capacidade civil. Há casos em que o sujeito pode ser incapaz civilmente de exercer atos da vida civil; entretanto, pode ter capacidade sucessória, como o recém-nascido. O caso emblemático referido por Pontes de Miranda é o do pai que falece no leito após relações sexuais ${ }^{1}$. Uma vez concebido, terá capacidade sucessória sem ter nascido e sem ter capacidade civil.

1 PONTES DE MIRANDA, Francisco Cavalcanti. Tratado de direito privado. Parte Especial. Tomo LVIII. Direito das sucessões: Sucessão testamentária. Disposições testamentárias em geral. Formas ordinárias do testamento. Atualizado por Vilson Rodrigues Alves. Campinas: Bookseller, 2009, p. 26. 
A capacidade para suceder diz respeito à qualidade para herdar do sucessível. Diz Salomão de Araújo Cateb que "o incapaz não recebe herança alguma, a ele não é deferido o direito sucessório".

A capacidade sucessória deve ser aferida ao tempo da abertura da sucessão, que se regulará conforme a lei em vigor, como dita o art.1.787 do Código Civil: "Regula a sucessão e a legitimação para suceder a lei vigente ao tempo da abertura daquela”.

Essa delimitação temporal é de suma importância, pois significa que a lei vigente ao tempo do falecimento é a que fixa a legitimação do herdeiro, de sorte que nenhuma alteração legislativa, anterior ou posterior ao óbito, poderá alterar o poder aquisitivo dos herdeiros. Em suma, a legitimidade deverá ser verificada ao tempo do falecimento.

Essas noções preliminares são necessárias para a análise dos institutos da indignidade e da deserdação que pressupõem a legitimidade do herdeiro. O herdeiro, por força de lei ou da vontade do testador, poderá ser excluído da sucessão. Portanto, ele tem legitimidade e chega a receber a herança, por força da transmissão do art. 1.784 do Código Civil, regra esta peremptória no ordenamento pátrio. Contudo, repise-se, os institutos da indignidade e deserdação estabelecem que os indigitados percam a parcela que lhes foi destinada por lei.
$\mathrm{O}$ presente artigo destina-se a debater tais institutos, bastante confundidos até pouco tempo. Essa confusão deriva da finalidade dos institutos: ambos visam afastar da herança aquelas pessoas que praticaram atos reprováveis em relação ao autor da herança. Contudo, a indignidade é uma pena cominada pela própria lei, nas hipóteses por ela elencadas. Já a deserdação é a pena imputada pela vontade exclusiva do autor da herança. Quanto às pessoas sujeitas, na indignidade, podem ser declarados indignos qualquer herdeiro legítimo, bem como o legatário; na deserdação, só pode ser deserdado herdeiro necessário.

Este artigo também propõe analisar as causas, trazer algumas situações instigantes, como o suicídio assistido, analisar legislações alienígenas e analisar os efeitos, tanto na dogmática brasileira como os meios processuais viáveis para o afastamento do direito à herança pelo herdeiro.

\section{PARTE I - INDIGNIDADE E DESERDAÇÃO}

\section{A) Conceitos}

\section{(i) Indignidade}

Trata-se de uma pena civil que priva o herdeiro ou o legatário do direito de aquisição por herança. $\mathrm{O}$ 
herdeiro ou o legatário que comete alguma falta grave contra o autor da herança e seus familiares é excluído da sucessão, ou seja, perde o direito de receber o quinhão ou o legado, uma vez tendo se tornado indigno de tal beneficiamento.

Importante ressaltar que o legislador previu essa penalidade não só para faltas graves cometidas contra o autor da herança, mas estendeu-a àqueles atos praticados em relação a seus familiares, ampliação essa contemplada pelo Código Civil de 2002, ao estender a calúnia ou crimes contra honra ao seu cônjuge ou companheiro, como veremos adiante. Urge destacar, preliminarmente, a valorização da família, reconhecida tanto no seu espectro coletivo, como base da sociedade, como no seu espectro restrito $^{2}$, com base no texto constitucional do art. 226. Tal inovação legislativa decorre do reconhecimento da existência de um sentimento íntimo que uma pessoa nutre em relação a determinados familiares, de modo a ela própria sentir-se atingida em caso de ataque à vida deles, como justifica Washington de Barros Monteiro ${ }^{3}$.

O fundamento da indignidade é ético, pois a ordem jurídica e a moral repudiam a viabilidade de alguém auferir vantagem patrimonial daquele a quem ofendeu. Afirma Washington de Barros Monteiro ${ }^{4}$ que "inspira-se o instituto da indignidade num princípio de ordem pública, porque à consciência social repugna, sem dúvida, que uma pessoa suceda a outra, depois de haver cometido contra estes atos lesivos de certa gravidade”.

As causas de exclusão da sucessão por indignidade estão arroladas no art.1.814 do Código Civil e constituem um rol taxativo, inadmitindo-se interpretação extensiva ou aplicação analógica, pois são uma penalidade, sendo aplicável o brocardo nulla poena sine lege. Diz o artigo:

Art.1.814. São excluídos da sucessão os herdeiros ou legatários:

I - que houverem sido autores, coautores ou partícipes de homicídio doloso, ou tentativa deste, contra a

2 Diz Arx Tourno, parafraseado por Alexandre de Moraes (Direito constitucional). $20^{\mathrm{a}}$ ed. São Paulo Atlas, 2006. p. 780: "Na acepção restrita, família abrande os pais e os filhos, um dos pais e os filhos, o homem e a mulher em união estável, ou apenas irmãos.... É na acepção strictu sensu que mais se utiliza o termo família, principalmente do ângulo do jus positum...”.

3 MONTEIRO, Washington de Barros. Curso de Direito Civil, V. 6: direito das sucessões. $37^{a}$ ed., atualização de Ana Cristina de Barros Monteiro França Pinto. Ed. São Paulo: Saraiva, 2009, p. 65.

4 Op. Cit., p. 63. 
pessoa de cuja sucessão se tratar, seu cônjuge, companheiro, ascendente ou descendente;

II - que houverem acusado caluniosamente em juízo o autor da herança ou incorrerem em crime contra a sua honra, ou de seu cônjuge ou companheiro; III - que, por violência ou meios fraudulentos, inibirem ou obstarem o autor da herança de dispor livremente de seus bens por ato de última vontade.

O inciso I tutela os casos de atentados contra a vida do autor da herança. A norma deixa claro que tal ato exige o elemento doloso, de forma que essa pena de exclusão não se aplica aos casos de homicídio culposo por negligência, imprudência ou imperícia, de error in persona, de aberraio ictus, de legítima defesa, estado de necessidade, exercício regular de um direito, loucura ou embriaguez. Isso porque o ato não é voluntário ou o autor do ato é inimputável, ou seja, não tinha a consciência.

A indignidade por ato contra a vida prescinde de sentença penal condenatória. Contudo, o delito do homicídio doloso ou atentado deve ser devidamente comprovado. Meras suspeitas não ensejam a indignidade. A prova de ato contra a vida pode ser produzida no juízo cível; porém, sustenta Maria Helena Diniz ${ }^{5}$ que havendo absolvição na esfera penal, pelo reconhecimento de uma excludente de criminalidade, superada estaria a questão na esfera civil. Isso significaria uma exceção ao princípio da independência das responsabilidades, estatuída no art. 935 do Código Civil ${ }^{6}$. Assim, uma vez absolvido, o herdeiro ou legatário não seria declarado indigno no juízo cível. Mas nem todos julgados da esfera criminal afastam a declaração de indignidade no juízo cível: não terá reflexo na indignidade a extinção da pena por prescrição ou indulto evidentemente.

Destaque-se que o indigno não precisa ser autor exclusivo do crime. Sua coautoria também é mote para a penalidade civil. Na verdade, a forma de participação no crime ou na sua tentativa é suficiente para afastá-lo da sucessão, como leciona Washington de Barros Monteiro?.

5 MONTEIRO, Washington de Barros. Curso de direito civil brasileiro. V. 6.: direito das sucessões. 24. ed., São Paulo: Saraiva, 2010, p. 52.

6 Art. 935. A responsabilidade civil é independente da criminal, não se podendo questionar mais sobre a existência do fato, ou sobre quem seja o seu autor, quando estas questões se acharem decididas no juízo criminal.

7 MONTEIRO, Washington de Barros. Curso de direito civil brasileiro. V. 6.: direito das sucessões. 24. ed., São Paulo: Saraiva, 2010, p. 64. 
Alta indagação advém se a instigação ao suicídio deve ser comparada ao homicídio, para efeito de indignidade. Temos que a resposta é afirmativa, caso houver indícios da instigação dolosa, visando o beneficiamento patrimonial do assediador. Tal prova poderia ser até considerada diabólica, mas de inegável necessidade, em face da gravidade da penalidade a ser aplicada.

Ainda na mesma análise do inciso I, não tardará discutirmos o suicídio assistido como causa de indignidade. No Brasil, a matéria não tem sido enfrentada, como o têm diversas legislações ocidentais. Na Inglaterra, o suicídio assistido é proibido, o que fez com que diversas pessoas migrassem para a Suíça, onde é tolerado, nos seguintes termos do art.115 do Código Penal: "Celui qui, poussé par un mobile égoïste, aura incité une personne au suicide, ou lui aura prêté assistance en vue du suicide, sera, si le suicide a été consommé ou tenté, puni d'une peine privative de liberté de cinq ans au plus ou d'une peine pécuniaire”. A Suíça possui poucas clínicas que permitem o suicídio assistido. O que temos visto na imprensa internacional é que pessoas de países próximos deslocam-se para o território helvético para poder praticar o suicídio, em caso de enfermidades graves ou estados terminais. Como consequência, tem-se visto também diversos parentes que acompanharam os enfermos serem presos ao retornar aos seus países de origem, obrigando-os a ajuizarem habeas corpus preventivos para responderem as ações penais em liberdade. Se na esfera penal tais têm sido os desdobramentos, não poderemos, logo mais, fugir do questionamento dos efeitos patrimoniais de tal prática, ficando aqui como ponto de reflexão.

Segunda hipótese de indignidade versada no inciso II do art. 1.814 do Código Civil é o de acusação caluniosa ou prática de crime contra a honra do falecido, de seu cônjuge ou companheiro.

As definições desses atos causadores de indignidade são previstos pelo Código Penal. Os crimes contra a honra estão normatizados nos arts.138 a 140 e consistem na calúnia, difamação e injúria, a saber:

\section{Calúnia}

Art. 138 - Caluniar alguém, imputando-lhe falsamente fato definido como crime:

$\S 1^{\circ}$ - Na mesma pena incorre quem, sabendo falsa a imputação, a propala ou divulga.

$\S 2^{\circ}$ - É punível a calúnia contra os mortos.

\section{Difamação}

Art. 139 - Difamar alguém, imputando-lhe fato ofensivo à sua reputação.

\section{Injúria}

Art. 140 - Injuriar alguém, ofendendo-lhe a dignidade ou o decoro.

Veja que a lei penal prevê no $2^{\circ}$. do art. 138 como crime a calúnia con- 
tra os mortos. Conjugando-se essa previsão penal com a penalidade civil da indignidade, reforça-se a valorização do elemento ético e moral da pessoa, que deve ser preservado não só em vida como após seu óbito.

Maria Helena Diniz, parafraseando Orlando Gomes, diz que a expressão crime contra a honra abrange as ofensas contra a memória do morto. Washington de Barros Monteiro $^{8}$ esclarece que as ofensas passíveis de gerar a pena da indignidade têm, necessariamente, de ser articuladas no juízo criminal, mediante queixa, que se revele falsa e dolosa. Assim, as ofensas veiculadas em ação cível (separação judicial, reclamatória trabalhista etc) não acarretariam indignidade.

Quanto à necessidade de condenação ou não do ofensor, divergem Carlos Maximiliano e Washington de Barros Monteiro. Para o primeiro, despicienda é a condenação do herdeiro ou legatário para sua exclusão. Já para o segundo, a prática de crimes contra a honra só será configurada se houver prévia condenação no juízo criminal ${ }^{9}$.
Terceira e última causa de indignidade é a prática de atos de violência ou de fraude que inibam ou obstem o autor da herança de dispor livremente de seus bens por testamento. É o caso do inciso III do art.1.814 do Código Civil. O intento da norma é proteger a liberdade do testador. Há uma plêiade de atos que podem atingir o ânimo livre e voluntário do testador, como a coação, corrupção, alteração, falsificação, inutilização, ocultação, impedimento etc ${ }^{10}$. São as hipóteses, por exemplo, do legatário que oculta testamento cerrado ou particular, que impede de revogar ou modificar testamento anterior. Apesar de tais atos não constituírem delitos penais, sua ocorrência, uma vez provada, tem o condão de gerar a declaração de indignidade.

O Código Civil ressalva em seu art.1.818 que não haverá punição caso o legatário corrija seus atos antes da produção dos efeitos:

Art. 1.818. Aquele que incorreu em atos que determinem a exclusão da herança será admitido a suceder, se o ofendido o tiver expressamente reabilitado em testamento, ou em outro ato autêntico.

8 MONTEIRO, Washington de Barros. Curso de direito civil brasileiro. V. 6.: direito das sucessões. 24. ed., São Paulo: Saraiva, 2010, p. 65.

9 Idem, p. 66.

10 Com clareza, elenca Washington de Barros Monteiro (2010, p. 66): “Na doutrina, são estes os casos geralmente apontados: a) o herdeiro constrange o de cujus a testar; b) ou então impede-o de revogar testamento anterior; c) suprime testamento cerrado ou particular dele; d) urde ou elabora um testamento falso; e) cientemente, pretende fazer uso de testamento contrafeito”. 
Maria Helena Diniz justifica o intuito da lei e frisa a irreversibilidade do perdão ${ }^{11}$ :

Ninguém melhor do que este [o ofendido] para avaliar o grau de ofensa. O direito de perdoar é privativo e formal; tem o condão de revogar os efeitos da indignidade e de admitir o ofensor à herança, reabilitando-o. Para tanto, a lei impõe ao ofendido a declaração expressa em testamento ou ato autêntico, como a escritura pública, de que, apesar da ofensa recebida, o ofensor deve ser chamado a gozar os benefícios da sucessão. Uma vez concedido o perdão, este será irretratável, não mais se reconhecendo aos coerdeiros legitimação para reabrir o debate.

O parágrafo único do art.1.818 do Código Civil tutela a reabilitação tácita, ou seja, o ofendido, sabendo da ofensa, contempla o indigno com um legado, demonstrando que não quer a sua punição. Eis o teor da norma:

Parágrafo único. Não havendo reabilitação expressa, o indigno, contemplado em testamento do ofendido, quando o testador, ao testar, já conhecia a causa da indignidade, pode suceder no limite da disposição testamentária.

\section{(ii) Deserdação}

A deserdação é uma cláusula testamentária na qual o testador exclui um ou mais herdeiros necessários do recebimento de sua legítima, declinando, para tanto, a causa legal. É uma pena civil, como a indignidade; entretanto, provém da vontade exclusiva do autor da herança. É a única forma que tem o testador de afastar os herdeiros necessários da sua sucessão. Diz o art. 1.961 do Código Civil: “Os herdeiros necessários podem ser privados de sua legítima, ou deserdados, em todos os casos em que podem ser excluídos da sucessão". Consequentemente, não há deserdação das demais categorias de herdeiros legítimos, como os colaterais. Estes, apesar de legítimos, não são herdeiros necessários. Para afastá-los da sucessão, pode o testador simplesmente dispor a universalidade de seus bens, como permite o art. 1.850 do Código Civil: "Para excluir da sucessão os herdeiros colaterais, basta que o testador disponha de seu patrimônio sem os contemplar”. Nesse caso, é dispensável fazer qualquer justificativa.

Se as causas de indignidade visam o resguardo da ordem social ${ }^{12}$, porque as causas de indignidade têm

\section{Idem, p. 60.}

12 Diverge Pontes de Miranda. Idem, p. 29: “A indignidade - que exclui os herdeiros e faz caducos os legados - não se funda em razão de ordem pública, mas em presunção da vontade do herdeiro. Por conseguinte, o testador pode obviar aos efeitos excludentes da lei, opor-se a eles, e a indignidade deixa de surtir efeitos”. 
uma conotação criminal acentuada, a deserdação vai além ${ }^{13}$, pois abarca aquelas e outras tantas que devem ser avaliadas pelo testador, medindo a intensidade de sua decepção, a graveza de seu desgosto ${ }^{14}$.

A partir do Código Civil de 2002, além dos descendentes e ascendentes, o cônjuge passou a integrar o rol de herdeiros necessários ${ }^{15}$, em determinados regimes de bens ${ }^{16}$. Portanto, podem ser deserdados.

O testador deverá amparar a deserdação em uma das causas previstas em lei. Podem ser tanto aquelas idênticas às de indignidade como as novas elencadas pelos art.1.962 e 1.963 do Código Civil. Ao analisar as hipóteses ensejadoras, vemos que o art.1.962 trata das causas em que os ascendentes podem deserdar os descendentes, ao passo que o art.1.963 trata da situ- ação inversa, criando situações díspares, criticadas pela doutrina ${ }^{17}$. Dizem tais normas:

Art. 1.962. Além das causas mencionadas no art. 1.814, autorizam a deserdação dos descendentes por seus ascendentes:

I - ofensa física;

II - injúria grave;

III - relações ilícitas com a madrasta ou com o padrasto;

IV - desamparo do ascendente em alienação mental ou grave enfermidade.

Art. 1.963. Além das causas enumeradas no art. 1.814, autorizam a deserdação dos ascendentes pelos descendentes:

I - ofensa física;

II - injúria grave;

III - relações ilícitas com a mulher ou companheira do filho ou a do neto, ou com o marido ou companheiro da filha ou o da neta;

13 VELOSO, Zeno. Comentários ao Código Civil: parte especial: direito das sucessões. V. 21 (arts. 1.857 a 2.027). AZEVEDO, Antônio Junqueira de (coord.). São Paulo: Saraiva, 2003, p. 310.

14 Ibidem, p. 311.

15 Art. 1.845. São herdeiros necessários os descendentes, os ascendentes e o cônjuge.

16 Art. 1.829. A sucessão legítima defere-se na ordem seguinte:

I - aos descendentes, em concorrência com o cônjuge sobrevivente, salvo se casado este com o falecido no regime da comunhão universal, ou no da separação obrigatória de bens (art. 1.640, parágrafo único); ou se, no regime da comunhão parcial, o autor da herança não houver deixado bens particulares.

17 Critica Washington de Barros Monteiro (2010, p. 243: “[...] o legislador deu injustificado tratamento diferente conforme os deserdados seja os ascendentes ou os descendentes: os primeiros podem ser deserdados se mantiverem relações ilícitas com o cônjuge ou companheiro do filho ou neto, indo, portanto, até o segundo grau na linha de descendente; os segundos, só com o cônjuge do ascendente, excluído, assim, o companheiro do ascendente, e limitando-se ao primeiro grau, pois só se refere ao padrasto ou madrasta". 
IV - desamparo do filho ou neto com deficiência mental ou grave enfermidade.

Vejamos de forma pormenorizada tais causas.

A ofensa física não carece gravidade, resquício, corpo de delito ou dor. Basta qualquer forma de agressão, justificando Sílvio de Salvo Venosa que o cerne é o desrespeito ${ }^{18}$. Não há necessidade de condenação penal. $\mathrm{O}$ que é levado em consideração é o mau tratamento corporal. Há necessidade de contato físico. Ameaças, intimidações, promessa de agressão futura, que amedrontem ou assustem a vítima não são causas de ofensa física; são tipificadas como injúria grave, causa do inciso II ${ }^{19}$. Ressalva Sílvio de Salvo Venosa que "a exemplo do direito penal, pode ser deserdado o herdeiro que foi o autor intelectual da agressão praticada por outrem" ${ }^{20}$.

Segunda causa é a injúria grave. Aqui, ao contrário da agressão física, a lei exige um grau de gravidade para a aplicação da pena de deserdação. A forma de exteriorização da in- júria pode ser a palavra, por meio da expressão verbal, oral ou por escrito (telegrama, cartas, bilhetes etc), bem como atos (gestos obscenos, condutas desonrosas), como elenca Zeno Veloso $^{21}$, acrescentando que "sem dúvida, 0 comportamento insultoso, as atitudes afrontosas e ultrajantes de um filho podem injuriar mais gravemente o pai, maltratá-lo de forma mais intensa e profunda, do que palavras ofensivas”.

Nelson Hungria, parafraseado por Zeno Veloso, define injúria:

é a manifestação, por qualquer meio, de um conceito ou pensamento que importe ultraje, menoscabo ou vilipêndio contra alguém. O bem jurídico lesado pela injúria é, prevalentemente, a chamada honra subjetiva, isto é, o sentimento da própria honrabilidade. Se na calúnia ou na difamação o agente visa, principalmente, ao descrédito moral do ofendido perante o terceiro, na injúria seu objetivo primacial é ferilo no seu brio ou pudor ${ }^{22}$.

Zeno Veloso grifa que o conceito civil é mais amplo que o penal ${ }^{23}$.

18 VENOSA, Sílvio de Salvo. Direito civil: direito das sucessões. V.7. $5^{\text {a }}$ ed. São Paulo: Atlas, 2005, p. 327.

19 Nesse sentido, VELOSO, Zeno. Idem, p. 330.

20 Idem, 241.

21 Idem, p. 330-331.

22 Idem, p. 331.

23 Idem, p. 331. 
Sílvio de Salvo Venosa leciona que é necessário examinar determinadas condições:

Simples desentendimentos não constituem injúria grave. Importa examinar o ânimo de injuriar, juntamente com as circunstâncias gerais que envolveram a conduta, tais como nível social e cultural dos envolvidos; situação em que ocorreu o evento; provocação da vítima etc. [...] O âmbito aqui deve ser visto de forma mais ampla. Pode a injúria exteriorizar-se pela palavra escrita, falada ou por gestos. A gravidade ficará jungida ao exame da prova e às condições de que falamos. A injúria deve ser contra a pessoa do testador e não contra terceira pessoa, ainda que muito querida por ele. A interpretação de norma punitiva não pode ser extensiva ${ }^{24}$.

Terceira causa são as relações ilícitas com a madrasta ou com o padrasto, no caso de sucessão descendente, e relações ilícitas com a mulher ou companheira do filho ou a do neto, ou com o marido ou companheiro da filha ou da neta, no caso de sucessão ascendente. Causa assaz estranheza que, na primeira, não há previsão de relações ilícitas com o companheiro ou companheira do ascendente. Washington de Barros Monteiro en- tende que, não estando previsto na lei, não se poderia estender a penalidade ${ }^{25}$. Contudo, a ideia destacada por Sílvio de Salvo Venosa fez-nos crer que o intuito da lei é repugnar relações sexuais que desequilibrem o lar e abalam a vítima ${ }^{26}$, razão pela qual cremos que, peculiarmente nesse caso, possa haver tal abrangência em relação a companheiros dos ascendentes.

Quarta e derradeira causa prevista é o desamparo do testador em estado de alienação mental ou grave enfermidade. O art.1.962, inc. IV, do Código Civil, prevendo o desamparo do ascendente, fala em alienação mental. Já o art.1.963, inc. IV, do mesmo Codex, fala em desamparo do filho ou neto com deficiência mental ou grave enfermidade. Prega Washignton de Barros Monteiro que as expressões alienação e deficiência mental se equivalem, cabendo à medicina definir em que consistem tais estados mentais patológicos ${ }^{27}$. Importa-nos saber que o desamparo previsto nas normas é de ordem econômica, ou seja, o parente tinha condições de aportar recursos para prover o doente e não o fez deliberadamente. Contudo, Sílvio de Salvo Venosa entende que "não se descarta o desamparo moral e intelectual, da dicção legal”"28.

24 Idem, p. 327.

25 Idem, p. 242.

26 Idem, p. 328.

27 Idem, 242.

28 Idem, p. 329. 
Incurso o deserdado em alguma dessas causas, o testador deverá descrever a situação, como determina o art. 1.964 do Código Civil: "Somente com expressa declaração de causa pode a deserdação ser ordenada em testamento". No caso de desamparo, por exemplo, o testador deverá descrever a enfermidade e a forma do desamparo. As mesmas justificativas são necessárias declinar na ocorrência dos outros motes de deserdação. Não são necessários detalhamentos; contudo, inegável que facilitariam o processo de prova pelo herdeiro ou pelo interessado na ação judicial própria, razão pela qual são aconselháveis. Elza de Faria Rodrigues, tabeliã de notas de Osasco, São Paulo, traz exemplo de cláusula testamentária com descrição da situação:

Nos termos do art. 1.964 do Código Civil, a testadora impõe a seu filho PEDRO CARLOS, a pena de deserdação em virtude dele haver ofendido moralmente a testadora, proferindo em tom alto, ou seja, gritando por cerca de dez minutos, palavras impróprias, rudes, obscenas, agressivas, imorais e ofensivas, gerando toda sorte de humilhação, angústia e transtornos, que causaram graves perturbações de saúde, inclusive distúrbios psíquicos. $\mathrm{O}$ terrível fato se passou em sua festa de aniversário em (dia/mês/ano), que ocorreu em sua residência, localizada na rua ..., na cidade de ******, contando, ainda, o evento com a presença de vários familiares e amigos que a tudo presenciaram, que poderá ser provado, incidindo, assim, na deserdação editada no Código Civil, inciso II - injúria grave. Assim, quer e determina que seu herdeiro necessário, ou seja, seu filho PEDRO CARLOS, seja privado da herança, em sua totalidade, acrescentando o seu quinhão ao dos outros herdeiros necessário ${ }^{29}$.

Acerca dessa redação exemplificativa, cumpre destacar que, se a deserdação for feita em termos amplos, a presunção é a de que atinge também a parte disponível. "No silêncio da vontade do disponente, a vocação é da ordem legítima, em toda a herança”, como leciona Sílvio de Salvo Venosa $^{30}$. Portanto, tanto o objeto da deserdação será a universalidade da herança como o destino dos bens que caberiam ao deserdado será a aplicação conforme a ordem da vocação hereditária, salvo determinação contrária em testamento. Zeno Veloso hasteia a possibilidade de a deserdação ser parcial, ao contrário de tantos outros juristas brasileiros. Sustenta ele tal ideia na ausência de proibição legal em nosso ordenamento e na pos-

29 Testamentos: teoria e prática. Belo Horizonte: Del Rey, 2011. p. 249.

30 Idem, p. 332. 
sibilidade praticada em outros países, como Chile, Bolívia e Alemanha, este último por construção doutrinária.

Ainda quanto aos cuidados com a redação, a disposição deve ser explícita, direta, clara e induvidosa, não podendo subordinar-se a deserdação a termo ou condição, ou seja, a evento futuro e incerto, a teor do art. 121 do Código Civil ${ }^{31}$.

A deserdação pode ser instituída em qualquer forma de testamento, inclusive as especiais ${ }^{32}$, uma vez inexistente qualquer restrição legal.

A maciça doutrinada tende a aplicar o perdão, previsto no art. 1.818 do CC para os casos de indignidade, para o instituto da deserdação ${ }^{33}$. O perdão extinguiria a deserdação, o que pode ser feito com a revogação do testamento ou elaboração de novo sem a repetição da deserdação.

\section{B) Previsão no Direito}

\section{Comparado}

\section{(i) Indignidade}

$\mathrm{O}$ instituto da indignidade como pena civil tem previsão em diversos ordenamentos jurídicos.

No caso da indignidade por prática de atos contra a vida, o Direito Por- tuguês, Belga e Francês exigem a prévia condenação criminal do herdeiro ou do legatário. O Direito Português alia diretamente a indignidade à incapacidade, conforme art. 2.034 do seu Código Civil:

Art. 2.034. Incapacidade por indignidade.

Carecem de capacidade sucessória, por motivo de indignidade:

1. O condenado como autor ou cúmplice de homicídio doloso, ainda que não consumado, contra autor da sucessão ou contra seu cônjuge, descendente, ascendente, adotante ou adotado;

2. O condenado por denúncia caluniosa ou falso testemunho contra as mesmas pessoas, relativamente a crime a que corresponda pena de prisão superior a dois anos, qualquer que seja a natureza;

3. O que por meio de dolo ou coação induziu o autor da sucessão a fazer, revogar, ou modificar o testamento, ou disso o impediu;

4. O que dolosamente subtraiu, ocultou, inutilizou, falsificou ou suprimiu o testamento, antes ou depois da morte do autor da sucessão, ou se aproveitou de alguns desses factos.

Art. 2.035. Momento da condenação do crime.

1. A condenação a que se referem as alíneas a) e b) do artigo anterior pode ser posterior a abertura da sucessão,

31 Art. 121. Considera-se condição a cláusula que, derivando exclusivamente da vontade das partes, subordina o efeito do negócio jurídico a evento futuro e incerto.

32 Neste sentido, Zeno Veloso. Idem, p. 337.

33 Neste sentido, Sílvio de Salvo Venosa. Idem, p. 322. Zeno Veloso. Idem, p. 326. 
mas só o crime anterior releva para o efeito.

2. Estando dependente de condição suspensiva instituição de herdeiro ou a nomeação de legatário, é relevante o crime cometido até a verificação de legatário, é relevante o crime cometido até a verificação da condição.

Art. 2.036. Declaração de indignidade. A ação destinada a obter a declaração de indignidade pode ser intentada dentro do prazo de dois anos a contar, quer da condenação pelos crimes que a determinam, quer do conhecimento das causas de indignidade previstas nas alíneas c) e d) do artigo 2.034.

Art. 2.037. Efeitos da indignidade.

1. Declarada a indignidade, a devolução da sucessão ao indigno é havida como inexistente, sendo ele considerado, parta todos os efeitos, possuidor de má-fé dos respectivos bens.

2. Na sucessão legal, a capacidade do indigno não prejudica o direito de representação.

O Código Civil Espanhol também tutela a indignidade. Contemplava, inicialmente, seis hipóteses no art. 756. Em 18 de novembro de 2003, foi acrescentado o $\S 7^{\circ}$. pelo art. 10 da Lei n. 41/2003 para incluir a proteção de ativos de pessoas com deficiência, senão vejamos:

Son incapaces de suceder por causa de indignidad:

1. Los padres que abandonaren, prostituyeren o corrompieren a sus hijos.

2. El que fuere condenado en juicio por haber atentado contra la vida del testador, de su cónyuge, descendientes o ascendientes. Si el ofensor fuere heredero forzoso, perderá su derecho a la legítima.

3. El que hubiese acusado al testador de delito al que la ley señale pena no inferior a la de presidio o prisión mayor, cuando la acusación sea declarada calumniosa.

4. El heredero mayor de edad que, sabedor de la muerte violenta del testador, no la hubiese denunciado dentro de un mes a la justicia, cuando ésta no hubiera procedido ya de oficio. Cesará esta prohibición en los casos en que, según la ley, no hay la obligación de acusar.

5. El que, con amenaza, fraude o violencia, obligare al testador a hacer testamento o a cambiarlo.

6. El que por iguales medios impidiere a otro hacer testamento, o revocar el que tuviese hecho, o suplantare, ocultare o alterare otro posterior.

7. Tratándose de la sucesión de una persona con discapacidad, las personas con derecho a la herencia que no le hubieren prestado las atenciones debidas, entendiendo por tales las reguladas en los artículos 142 y 146 del Código Civil.

\section{(ii) Deserdação}

Discorrendo acerca da "in/justiça" do instituto da deserdação, Zeno Veloso registra que em alguns países, não há que se falar em deserdação, porque a liberdade de dispor de seus bens por testamento é ilimitada, absoluta, inexistindo restrição à disposição patrimonial, tampouco resguardo de herança aos herdeiros 
necessários, como na Inglaterra, Estados Unidos e México ${ }^{34}$.

Já as legislações da França, Bélgica, Itália e Venezuela optaram por não prever a deserdação, deixando a matéria da exclusão da sucessão no âmbito da indignidade ${ }^{35}$.

A deserdação é instituto previsto nas legislações civis de Portugal, Espanha, Suíça, Áustria, Alemanha, Argentina, Uruguai, Paraguai, Peru, Chile, Colômbia e Macau ${ }^{36}$. Vejamos, pois, os textos normativos que estipulam as causas no Direito Português e Espanhol respectivamente:

Artigo 2.166. Deserdação.

1. O autor da sucessão pode em testamento, com expressa declaração da causa, deserdar o herdeiro legitimário, privando-o da legítima, quando se verifique alguma das seguintes ocorrências:

a. Ter sido o sucessível condenado por algum crime doloso cometido contra a pessoa, bens ou honra do autor da sucessão, ou do seu cônjuge, ou algum descendente, ascendente, adotante ou adotado, desde que ao crime corresponda pena superior a seis meses de prisão;

b. Ter sido o sucessível, sem justa causa, a recusado ao autor da sucessão; c. Ter o sucessível, sem justa causa, recusado ao autor da sucessão ou ao seu cônjuge os devidos alimentos.

2. O deserdado é comparado ao indigno para todos os efeitos legais.

\section{Artículo 852}

Son justas causas para la desheredación, en los términos que específicamente determinan los artículos 853, 854 y 855 las de incapacidad.

\section{Artículo 853}

Serán también justas causas para desheredar a los hijos y descendientes, además de las señaladas en el artículo 756 con los números $2 .^{\circ}, 3 .^{\circ}, 5 .^{\circ}$ y $6 .^{\circ}$, las siguientes:

1. Haber negado, sin motivo legítimo, los alimentos al padre o ascendiente que le deshereda.

2. Haberle maltratado de obra o injuriado gravemente de palabra.por indignidad para suceder, señaladas en el artículo 756 con los números $1 .^{\circ}$, 2. ${ }^{\circ}, 3 .^{\circ}, 5 .^{\circ}$ y $6 .^{\circ}$.

\section{Artículo 854}

Serán justas causas para desheredar a los padres y ascendientes, además de las señaladas en el artículo 756 con los números $1 .^{\circ}$, $2 .^{\circ}, \quad 3 .^{\circ}, 5 .^{\circ}$ y $6 .^{\circ}$, las siguientes: 1. Haber perdido la patria potestad por lascausasexpresadasenelartículo170.

34 VELOSO, Zeno. Comentários ao Código Civil: parte especial: direito das sucessões, vol.21 (arts. 1.857 a 2.027). AZEVEDO, Antônio Junqueira de (coord.). São Paulo: Saraiva: 2003, p. 307.

35 Idem, p. 307.

36 Idem, p. 307. 
2.Habernegadolosalimentosasushijos o descendientes sin motivo legítimo. 3. Haber atentado uno de los padres contra la vida del otro, si no hubiere habido entre ellos reconciliación.

\begin{abstract}
Artículo 855
Serán justas causas para desheredar al cónyuge, además de las señaladas en el artículo 756 con los núme$\operatorname{ros} 2 .^{\circ}, 3 .^{\circ}, 5^{\circ}$ y $6 .^{\circ}$, las siguientes: 1. Haber incumplido grave o reiteradamente los deberes conyugales.

2. Las que dan lugar a la pérdida de la patria potestad, conforme al artículo 170.

3. Haber negado alimentos a los hijos o al otro cónyuge.

4. Haber atentado contra la vida del cónyuge testador, si no hubiere mediado reconciliación.
\end{abstract}

Alguns ordenamentos estrangeiros preveem a deserdação com boa intenção. O Direito Alemão prevê no $\S 2.338$ de seu Código Civil a proteção do descentente herdeiro, que seja pródigo ou esteja gravemente endividado, a ponto de sua futura herança correr perigo. Assim, o testador pode limitar seu direito à legítima, ordenando que, depois da morte do descendente pródigo ou endividado, seus herdeiros legítimos devam receber o que foi a ele deixado ${ }^{37}$. O Código Suíço, no art. 4.810, regula a deserdação preventiva: no caso de o descendente ter diversas execuções, o testador pode privá-lo da metade da sua legítima e relegá-la a um filho do endividado, nascido ou por nascer. No direito brasileiro, inexiste tal hipótese. Ocorre, todavia, a inserção nos testamentos de gravames de inalienabilidade, impenhorabilidade e incomunicabilidade, muito embora seja corrente o cancelamento de tais restrições por pecha de inconstitucionalidade ${ }^{38}$.

\section{EFEITOS}

\section{Ações cabíveis}

\section{(i) Indignidade}

A indignidade só pode ser declarada judicialmente. Portanto, deverá ser objeto de ação ordinária, como se extrai do art. 1.815 do Código Civil: "A exclusão do herdeiro ou legatário, em qualquer desses casos de indignidade, será declarada por sentença”.

Outrossim, considerando que a indignidade é uma penalidade civil

37 VELOSO, Zeno. Idem, p. 327.

38 Neste sentido: “Testamento. Inalienabilidade. Impenhorabilidade e Incomunicabilidade. Desaparecimento dessas cláusulas no Direito Brasileiro. As cláusulas testamentárias de inalienabilidade, impenhorabilidade e incomunicabilidade, além de prejudiciais, não foram recepcionadas pelos sistema constitucional vigente no Brasil. [...]” (RJTJRGS, 183/177. Rel. Des. Sérgio Gischkow Pereira). 
aplicada pelo juiz, sua natureza é meramente declaratória. O juiz não constitui nem desconstitui, a priori, qualquer relação jurídica existente entre as partes. Na verdade, a relação jurídica de sucessão legítima ou testamentária persiste, operando por sentença um efeito de declaração da incapacidade sucessória $^{39}$. Daí porque a doutrina entende que, dentro da classificação ternária clássica, a natureza jurídica da sentença é declaratória ${ }^{40}$.

Normalmente, a ação de indignidade é ajuizada por quem tenha legítimo interesse, na forma dos arts. $3^{\circ}$ e $6^{\circ}$ do Código de Processo Civil, isto é, por algum coerdeiro, legatário, donatário. Até mesmo o Fisco é referido como legitimado, na ausência de sucessores. Igualmente, qualquer credor, prejudicado com a inércia dos demais.

A doutrina divide-se quanto à legitimidade do Ministério Público para a interposição da ação. Maria Helena Diniz $^{41}$ alinha-se no grupo que defende que a omissão da atribuição ao Ministério Público no atual Código Civil de 2002 não lhe retira a legitimidade outorgada pelo art. 127 da Constituição Federal, segundo o qual "O Ministério Público é instituição permanente, essencial à função jurisdicional do Estado, incumbindo-lhe a defesa da ordem jurídica, do regime democrático e dos interesses sociais e individuais indisponíveis”. Dessa feita, a defesa da ordem jurídica e o interesse social seriam os motes para evitar que o herdeiro ou legatário desnaturado fosse beneficiado com a fortuna deixada pela sua vítima. O Conselho da Justiça Federal aprovou em 2004, na III Jornada de Direito Civil ${ }^{42}$, o Enunciado n.116 que diz: "O Ministério Público, por força do art. 1.815 do novo Código Civil, desde que presente o interesse público, tem legitimidade para promover ação visando à declaração da indignidade de herdeiro ou legatário”. Já a vertente contrária à legitimidade do Ministério Públi$\mathrm{CO}^{43}$ entende que a ação é de natureza estritamente privada, descabendo tal múnus ao custus legis.

39 Em verdade, ilegitimidade. Vide considerações feitas na introdução deste trabalho.

40 Diz Washington de Barros Monteiro. Idem, p. 67: “A sentença não é título constitutivo, mas apenas declarativo da incapacidade para suceder”.

41 Idem, p. 54.

42 Cumpre lembrar que tais Jornadas têm o escopo de promover debates de temas sugeridos pelo novo Código Civil e aprovar enunciados que representem o pensamento da maioria dos integrantes de cada uma das diversas comissões. Não está claro, ainda, se tais enunciados têm finalidade de propor alterações legislativas ou de servir de orientações para os operadores do direito.

43 Nesse sentido, MONTEIRO, Washington de Barros Monteiro. Idem, p. 67. 
A ação de indignidade tramitará pelo rito ordinário, permitindo ampla defesa por parte do réu.

A ação de indignidade só pode ser ajuizada enquanto vivo o suposto indigno. Se vier a falecer, inviável o ajuizamento da ação declaratória de indignidade porque não há como imputar uma penalidade civil a quem já faleceu. Consequentemente, seu óbito extingue a ação.

Uma vez ajuizada ação de indignidade, o réu prosseguirá com o domínio e posse da herança, até o provimento declaratório transitado em julgado, quando será excluído da sucessão. Se falecer antes da declaração, seu direito à herança passará a seus sucessores.

O prazo para interposição da ação declaratória de indignidade é de quatro anos, a partir da abertura da sucessão. Trata-se de prazo de natureza decadencial, como se depreende do art.1.815,§ único, do Código Civil: "O direito de demandar a exclusão do herdeiro ou legatário extingue-se em quatro anos, contados da abertura da sucessão”. Esse já era o prazo previsto no Código Civil de 1916, especificamente no art.178, § IV. A mantença do mesmo lapso ensejou críticas, chegando a ser objeto do Projeto de Lei de Alteração do Código Civil, para, dentre outras matérias, reduzir o prazo para dois anos.

\section{(ii) Deserdação}

Lavrado o testamento com a cláusula de deserdação, uma vez ocorrido o óbito do testador, o testamento é apresentado. A partir desse momento, o herdeiro ou o interessado tem quatro anos para ajuizar a ação ordinária de declaração de deserdação, no qual deverá ser provada a veracidade da causa arguida pelo testador. Diz o Código Civil:

Art. 1.965. Ao herdeiro instituído, ou àquele a quem aproveite a deserdação, incumbe provar a veracidade da causa alegada pelo testador.

Parágrafo único. O direito de provar a causa da deserdação extingue-se no prazo de quatro anos, a contar da data da abertura do testamento.

Vê-se que o interessado deve propor a ação. O testamenteiro não contemplado por legado não pode propor a ação, como anota Washington de Barros Monteiro ${ }^{44}$. Mas se o interessado não propuser, diz o referido jurista que pode o próprio deserdado propor ação cominatória, para o que o interessado prove o fundamento da deserdação, ressalvando que "o exercício dessa ação não o sujeita, porém, a 
comprovar a inexistência da causa em que a deserdação se funda”. Já Sílvio de Salvo Venosa entende que a ação cabível pelo deserdado seria a ação declaratória de inexistência de causa de deserdação, com esteio no art. $4^{\circ}$, I do $\mathrm{CPC}^{45}$.

Quanto ao prazo, o Código Civil de 1916 previa o prazo de quatro anos a partir da abertura da sucessão. O de 2002 alterou para a abertura do testamento, o que recebeu a crítica de Zeno Veloso ${ }^{46}$, para quem o marco inicial do prazo decadencial deveria ser a abertura da sucessão, o que é proposto no Projeto de Lei 6.960. Aliás, o Projeto também intenciona reduzir o prazo para dois anos.

Entenda-se por "abertura do testamento" o momento em que o juiz determina o cumprimento do testamento.

Ajuizada ação pelo interessado e não provada a veracidade da causa, a cláusula testamentária de deserdação será ineficaz ${ }^{47}$, e não nula, porque ela existe e era válida, mas não logrou surtir seus efeitos em face da ausência de comprovação exigida pela lei. O prazo tem natureza decadencial.

Caso frustrada a ação declaratória de deserdação, sustenta Zeno Veloso ser viável a ação com esteio na indignidade ${ }^{48}$.

Cônscio da dificuldade de produção de prova da veracidade da causa de deserção, propõe Zeno Veloso que seja admitido que o testador, em vida, requeira, em juízo, medida cautelar, pedindo a produção antecipada da prova, quanto à causa apontada como ensejadora da deserdação de seu herdeiro necessário, com base nos arts. 846 a 851 do Código de Processo Civil. E propugna a dispensa de ajuizamento de ação principal, dado o caráter satisfativo dessa cautelar ${ }^{49}$.

45 Idem, p. 325.

46 Idem, p. 337.

47 Assim sustenta Sílvio de Salvo Venosa. Idem, p. 323. Já Washington de Barros Monteiro entende que o efeito é a nulidade. Idem, p. 245. E talvez o faça com esteio na antiga redação do art.1.743, § único, do Código. Civil de 1916 que dizia: "Não se provando a causa invocada para a deserdação, é nula a instituição, e nulas as disposições, que prejudiquem a legítima do deserdado". Zeno Veloso entende que a deserdação é nula se o testamento é nulo. A deserdação é ineficaz por falta de declaração da causa, pela apresentação de causa não prevista em lei, pela ausência de prova de veracidade da causa. Idem, p. 324.

48 Idem, p. 313: "Observe-se que, se a deserdação vier a frustrar-se, por ser nulo o testamento, mas tiver como causa um fato que seja, também, motivo de indignidade, nada obsta que o interessado promova a respectiva ação com vistas à exclusão do herdeiro, invocando o art. 1.814".

49 Idem, p. 320. 


\section{Efeitos dentro da dogmática civil brasileira}

\section{(i) Indignidade}

Diz o art. 1.816 do Código Civil: "São pessoais os efeitos da exclusão; os descendentes do herdeiro excluído sucedem, como se ele morto fosse antes da abertura da sucessão”. Isso reflete em diversas situações, as quais passaremos a examinar.

Os efeitos da declaração de indignidade podem ser elencados como:

\section{(i.i) Intransmissibilidade da ex-} clusão aos descendentes do indigno, como antevisto pela norma do art. 1.816 do Código Civil. O tratamento dado ao indigno será uma equiparação ao que é dado ao herdeiro premorto, ou seja, seus descendentes o sucedem por representação. Frisa Maria Helena Diniz:

se abre exceção ao princípio de direito sucessório de que não se pode representar pessoa viva (viventis nulla esta representatio). Com isso acata-se o princípio constitucional da responsabilidade pessoal (CF, art. $5^{\circ}$., XLV) e a velha parêmia: nullum patris delictum innocenti filio poena est (nenhum crime o pai pode prejudicar o filho inocente). Os bens que o indigno deixa de herdar são devolvidos às pessoas que os herdariam, como se nunca tivesse sido herdeiro, devido ao caráter personalíssimo da pena, que não deve ultrapassar a pessoa do delinquente, ante a injustiça de estender-se a outrem as consequências de um fato a que se mostrou alheio.

A segunda parte do art.1.816 do Código Civil é claro ao delimitar o direito de representação somente aos descendentes, de sorte que, tendo indigno apenas ascendentes ou colaterais, estes não poderão substituir o indigno e receber sua parte na herança.

\section{(i.ii) Retroatividade dos efeitos} da sentença à data de abertura da sucessão e responsabilidade pela devolução. A retroatividade é decorrência lógica da lei, até porque esta equipara o indigno à situação do premorto. Assim, uma vez retroativos os efeitos da sentença declaratória de indignidade, o indigno, além de ser excluído da sucessão, responde por perdas e danos e é obrigado a devolver os frutos e rendimentos, como diz o art.1817, caput, do Código Civil ${ }^{50}$, mas tem o direito de ser reembolsado

50 “Art. 1.817. São válidas as alienações onerosas de bens hereditários a terceiros de boa-fé, e os atos de administração legalmente praticados pelo herdeiro, antes da sentença de exclusão; mas aos herdeiros subsiste, quando prejudicados, o direito de demandar-lhe perdas e danos”. 
no que haja gasto com a conservação dos bens, como diz o seu parágrafo único ${ }^{51}$.

\section{(i.iii) Irretroatividade dos efei-} tos da sentença em relação às alienações onerosas a terceiros. A retroatividade antes vista não atinge $\mathrm{o}$ direito de terceiros, como se vê da norma do art.1.817, caput $1^{\text {a }}$ parte, do Código Civil: "São válidas as alienações onerosas de bens hereditários a terceiros de boa-fé, e os atos de administração legalmente praticados pelo herdeiro, antes da sentença de exclusão". Portanto, o efeito aqui é distinto: opera-se ex nunc.

A norma prima pela preservação do terceiro adquirente de boa-fé, que não tinha condições de prever a futura exclusão do indigno, como bem analisa Maria Helena Diniz a partir de uma digressão histórica:

Opera a sentença ex nunc, validando atos praticados pelo herdeiro excluído até o momento de sua exclusão da sucessão, atendendo ao princípio da onerosidade da alienação e da boa-fé dos adquirentes, urna vez que o indigno se apresentava aos olhos de todos como herdeiro do hereditando, sendo, portanto, um herdeiro aparente, devido à impressão generalizada de ser 0 sucessor do de cujus. Desse modo, os adquirentes não podiam prever a futura exclusão do ingrato, pois acreditavam estar adquirindo os bens do verdadeiro proprietário, o que levou o legislador a sustentar a validade dos negócios onerosos efetuados pelo herdeiro aparente. Urge esclarecer a questão do herdeiro aparente. É o considerado como verdadeiro e legítimo titular do direito sucessório, embora não o fosse em razão de um erro (ignorância da existência de um herdeiro mais próximo do autor da herança; reconhecimento post mortem da paternidade de filho pelo de cujus), de exclusão da herança por indignidade ou deserdação, de falsidade ou nulidade de testamento.

No direito romano, o possessor pro herede, sob aparência de herdeiro, possuía de boa-fé bens hereditários. Em regra, seus atos de disposição não poderiam ter validade, ante o brocardo: nemo ad allium transferre potest quam ipse habet, mas o direito não pode prescindir das aparências, em prol da boa-fé, da paz e segurança social. É preciso levar em conta a boa-fé do adquirente, que acreditou não só na legalidade do ato negocial efetivado, mas também na condição de herdeiro do alienante, que até o instante da exclusão, aos olhos de todos, era o "real" herdeiro. Logo, merecem proteção jurídica as alienações feitas onerosamente pelo herdeiro aparente a terceiro de boafé (CC, art. 1.827, parágrafo único),

51 “§ Único: O excluído da sucessão é obrigado a restituir os frutos e rendimentos que dos bens da herança houver percebido, mas tem direito a ser indenizado das despesas com a conservação deles”. 
sob pena de acarretar instabilidade nas relações jurídicas, desde que levadas a efeito antes da exclusão. O verdadeiro herdeiro apenas poderá pleitear perdas e danos do excluído. $\mathrm{O}$ real herdeiro pode exigir do aparente a reposição patrimonial, mas não do terceiro adquirente de boa-fé, porque a lei lhe retira a eficácia reivindicatória da ação. Se a alienação for gratuita, não deverá ser mantida, porque não haverá qualquer dano, prevalecendo a situação do herdeiro real ${ }^{52}$.

Entretanto, caso esses terceiros tenham obrado de má-fé, ou seja, tivessem perfeito conhecimento da situação de indignidade, sofrerão os efeitos, tornando-se os negócios jurídicos ineficazes ${ }^{53}$.

\section{(i.iv) Perda do direito aos bens} da herança, em sucessão de seus descendentes, e direito de usufruto e administração. Assim como o indigno é excluído da sucessão, caso substituído por seus herdeiros por força do direito de representação estatuído no art. 1.816 do Código Civil, $2^{\mathrm{a}}$ parte, a lei não poderia permitir que ele fosse contemplado sob outro viés, sob pena de burla. Assim, vetou que o descendente pudesse instituir usufruto ou administração dos bens recebidos em representação do indigno, ou mesmo que pudesse transmiti-los aos indigitados. Se, na forma direta, ele é afastado da sucessão, tampouco poderá ser beneficiado por outros meios, visando a lei atingir seu fim precípuo: impedir o desnaturado do recebimento de qualquer vantagem do patrimônio de sua vítima. É o que diz o $\S$ único do art. 1.816 do Código Civil: "Parágrafo único. O excluído da sucessão não terá direito ao usufruto ou à administração dos bens que a seus sucessores couberem na herança, nem à sucessão eventual desses bens”. A norma é tão ampla que fala em vedação no caso de sucessão eventual, ou seja, no caso de o descendente falecer e não deixar novos descendentes, o ascendente declarado indigno não poderá receber tais bens.

\section{(ii) Deserdação}

Diz o art.1.961 do Código Civil: “Os herdeiros necessários podem ser privados de sua legítima, ou deserdados, em todos os casos em que podem ser excluídos da sucessão”. Daí, tiram-se os seguintes efeitos:

\section{(ii.i) Exclusão do herdeiro} necessário do recebimento da legítima. É o efeito principal da deserdação.

52 Idem, p. 58-59.

53 Nesse sentido, MONTEIRO, Washington de Barros Monteiro. Idem, p. 69. 
(ii.ii) Intransmissibilidade da exclusão aos descendentes do deserdado. O efeito é idêntico ao instituto da indignidade, por se tratar de uma sansão de caráter pessoal. A doutrina é maciça no sentido da aplicação do art.1.816 do Código Civil aos casos de deserdação ${ }^{54}$, razão pela qual reportamo-nos às justificativas do item 'i.ii', não sem antes registrar a posição contrária e isolada de Washington de Barros Monteiro, para quem não só o deserdado resta excluído da sucessão como também seus descendentes. Tal posicionamento pauta-se no fato de inexistir previsão expressa, como o faz o instituto da indignidade.

O Projeto de Lei de Alteração do Código Civil no 276 propõe eliminar a divergência, inserindo o $\S 2^{\circ}$ ao art. 1.965 com o seguinte teor:

$\S 2^{\circ}$ São pessoais os efeitos da deserdação: os descendentes do herdeiro deserdado sucedem, como se ele morto fosse antes da abertura da sucessão. Mas o deserdado não terá direito ao usufruto ou à administração dos bens a que seus sucessores couberem na herança, nem à sucessão eventual desses bens.

O Deputado Ricardo Fiúza, apresentante do Projeto, acata a sugestão de Zeno Veloso ${ }^{55}$ :

[...] embora, sob e égide do Código Civil de 1916, haja a opinião dominante de que os descendentes do deserdado tomam o lugar dele na herança, exercendo o direito de representação, pois a pena não pode se irradiar aos descendentes do que praticou os atos desabonadores, para espancar dúvidas, convém que esta solução seja dada expressamente na lei.

(i.iii) Perda do direito aos bens
da herança, em sucessão de seus
descendentes, e direito de usufruto
e administração. A maciça doutrina
dá idêntico tratamento à deserdação,
por analogia à indignidade ${ }^{56}$; contudo,
também nessa interpretação destoa
Washington de Barros Monteiro,
pela mesma razão acima referida,
qual seja, ausência de previsão pelo
legislador de $2002^{58}$.
da herança, em sucessão de seus descendentes, e direito de usufruto e administração. A maciça doutrina dá idêntico tratamento à deserdação, por analogia à indignidade ${ }^{56}$; contudo, também nessa interpretação destoa pela mesma razão acima referida, qual seja, ausência de previsão pelo legislador de $2002^{\text {se }}$

54 Assim sustentam: CAHALI, Francisco José. HIRONAKA, Giselda Maria Fernandes Novaes. Idem, p. 303. VENOSA, Sílvio de Salvo. Idem, p. 330. VELOSO, Zeno. Idem, p. 321.

55 FIUZA, Ricardo; com a colaboração de RÉGIS, Maria Luiz Delgado. O novo Código Civil e as propostas de aperfeiçoamento. São Paulo: Saraiva, 2004, p. 308.

56 VENOSA, Sílvio de Salvo. p. 330-331. Francisco José. HIRONAKA, Giselda Maria Fernandes Novaes. Idem, p. 304. VELOSO, Zeno. Idem, p. 322.

57 MONTEIRO, Washington de Barros. Idem, p. 247. 


\section{(i.iv) Retroatividade dos efeitos da sentença à data de abertura da sucessão. Como visto no início} do trabalho, aberta a sucessão, a herança transmite-se, desde logo, aos herdeiros e testamentários. Porém, havendo uma cláusula testamentária de deserdação, o deserdado, tendo conhecimento deste ato de última vontade, não deverá ter a posse dos bens, pelo princípio da Saisine. Estará ele de má-fé porque carece de título hereditário que o habilite. É o magistério de Silvio de Salvo Venosa:

O deserdado, por outro lado, já tem contra si uma causa expressa no testamento que o impede, de bom senso, que assuma a posse dos bens da herança. Se procedente o pedido de deserdação, nunca terá havido herança para o deserdado, nem posse dos bens hereditários. Ainda que, dentro do prazo decadencial, tome ele a iniciativa da ação, mesmo assim ele carece de título hereditário, que só lhe advirá com o decurso de prazo de caducidade, ou da ineficácia da cláusula decretada em juízo. Destarte, publicado e apresentado o testamento, o indigitado não se pode portar como herdeiro. Pode ocorrer que o deserdado exerça a posse material da herança, mas por outro título, seja a posse originalmente boa ou má, mas não por título hereditário.
Aliás, o inventariante, testamenteiro e demais interessados têm contra ele, em princípio, os interditos possessórios enquanto não definida sua situação, porque sua posse é injusta a partir da morte do autor da herança. Se o deserdado mantiver a sua posse após a sentença que assim o reconhecer, os demais interessados têm ação de petição de herança contra ele. No momento em que o testamento é publicado e notificado o herdeiro apontado, a partir daí cessa sua posse de boa-fés ${ }^{\text {. }}$.

Assim sendo, a priori, não deverá o deserdado assumir a posse dos bens, o que tornaria tranquila a aplicação dos efeitos da sentença declaratória julgada procedente. Já no caso de improcedência, a posse retroage à data da abertura da sucessão, tendo ele direito aos bens que lhe tocarem na legítima ${ }^{59}$.

No entanto, sabe-se que nem sempre a situação mostra-se tão fluída. Muitas vezes, tarda-se à abertura do testamento, desconhecendo o herdeiro necessário a pecha de deserdação contra si clausulada. Aliás, essa é a preocupação de Zeno Veloso, que reclama maior aprofundamento, concluindo pela mesma solução dada à indignidade ${ }^{60}$. Assim, propõe o jurista que os bens transmitam-se desde

58 Idem, p. 331.

59 VENOSA, Sílvio de Salvo. Idem, p. 331.

60 Idem, p. 323-324. 
logo aos herdeiros, de acordo com o princípio de Saisine, consagrado no art. 1.784 do Código Civil, exceto no caso de ingresso da ação declaratória de deserção, caso em que a herança tornar-se-ia litigiosa, devendo os bens passarem à posse do inventariante ou outra pessoa designada pelo juiz, mediante depósito judicial.

(i.v) Irretroatividade dos efeitos da sentença em relação às alienações onerosas a terceiros. Apregoa Sílvio de Salvo Venosa idêntico tratamento à deserdação dado às situações vislumbradas no caso da indignidade: As alienações de boa-fé realizadas pelo deserdado devem valer quando houver terceiro adquirente de boafé, devendo o deserdado responder pelas perdas e danos em relação aos herdeiros alijados ${ }^{61}$.

\section{CONSIDERAÇÕES FINAIS}

A leitura das normas e das lições doutrinárias evocam a impossibilida- de de alastramento das hipóteses de indignidade e deserdação, por constituírem ambas penas gravíssimas, impostas ao ofensor, que o extirpa de um direito fundamental, de primeira geração, garantido pelo art. $5^{\circ}$, inciso XXX, da Carta Magna.

Entretanto, vê-se que há situações que exigem do intérprete que ele compreenda o intuito da norma e proteja um bem maior. É forçoso reconhecer que não há como a lei tutelar todas as hipóteses fáticas possíveis, razão pela qual, até mesmo no caso de aplicação de uma penalidade civil extrema, não se pode retirar do julgador a sua inteligência e perspicácia na aplicação da lei. É o que vimos como resultado de todo o estudo a que se propôs o trabalho e podemos extrair de interessantes julgados, como o caso de declaração de indignidade do genro que, tendo assassinado seu sogro, foi afastado da partilha na ação de divórcio, por aplicação da declaração indignidade ${ }^{62}$. Casado pelo regime da comunhão universal, ele receberia a meação da herança do sogro por ele morto. Por não

61 Idem, p. 331.

62 “MEAÇÃO. DIVÓRCIO. INDIGNIDADE. QUEM MATOU O AUTOR DA HERANÇA FICAEXCLUÍDO DA SUCESSÃO. ESTE É O PRINCÍPIO CONSAGRADO NO INC. I DO ART. 1595 DO CC, QUE REVELA A REPULSA DO LEGISLADOR EM CONTEMPLAR COM DIREITO SUCESSÓRIO QUEM ATENTA CONTRA A VIDA DE ALGUÉM, REJEITANDO A POSSIBILIDADE DE QUE, QUEM ASSIM AGE, VENHA A SER BENEFICIADO COM SEU ATO. ESTA NORMA JURÍDICA DE ELEVADO TEOR MORAL DEVE SER RESPEITADA AINDA QUE O AUTOR DO DELITO NÃO SEJA HERDEIRO LEGÍTIMO. TENDO O GENRO ASSASSINA- 
ser considerado herdeiro, a sentença e o relator conduziram suas decisões pela impossibilidade de aplicação da pena de indignidade, do que divergiram a revisora e o vogal, em votos que primaram pelo intuito normativo: "No momento em que o legislador revelou a repulsa em contemplar com direito sucessório quem atentar contra a vida do autor da herança, a ponto de excluir o herdeiro da sucessão, nitidamente, rejeitou a possibilidade de que, quem assim age, ser beneficiado com seu ato". Com isso, verificamos que há uma plêiade de situações imprevisíveis e, por mais peremptória que veja a previsão normativa, não há como afastar da tutela judicial situações fáticas que reclamem a aplicação da pena.

\section{REFERÊNCIAS}

CAHALI, Francisco José; HIRONAKA, Giselda Maria Fernandes Novaes. Direito das sucessões. 3. ed. São Paulo: Ed. Revista dos Tribunais, 2007.

CATEB, Salomão de Araújo. Artigo: Indignidade e deserdação. Revista da Faculdade de Direito Milton Campos. Belo Horizonte, 1994. V.1, p. 243-252.

DINIZ, Maria Helena. Curso de direito civil brasileiro. Volume 6: Direito das sucessões. 24 ed. São Paulo: Saraiva, 2010.

FIUZA, Ricardo; RÉGIS, Maria Luiz Delgado (Col.); O NORONHA,
Carlos Silveira (Org.) As novas perspectivas do direito das sucessões: em tempos de modernidade e pós-modernidade. Porto Alegre: Sulina, 2011.

LEITE, Eduardo de Oliveira. Comentários ao novo código civil, volume XXI: arts. 1.784 a 2.027. Coord. Sálvio de Figueiredo Teixeira. $4^{\mathrm{a}}$. ed. Rio de Janeiro: Forense, 2005. MONTEIRO, Washington de Barros. Curso de Direito Civil, v.6: direito das sucessões. $37^{\mathrm{a}}$ ed., atualização de Ana Cristina de Barros Monteiro França Pinto. Ed. São Paulo: Saraiva, 2009.

DO O SOGRO, NÃO FAZ JUS AO ACERVO PATRIMONIAL DECORRENTE DA ABERTURA DA SUCESSÃO. MESMO QUANDO DO DIVÓRCIO, E AINDA QUE O REGIME DO CASAMENTO SEJA O DA COMUNHÃO DE BENS, NÃO PODE O VARÃO RECEBER A MEAÇÃO CONSTITUÍDA DOS BENS PERCEBIDOS POR HERANÇA. APELO PROVIDO POR MAIORIA, VENCIDO O RELATOR”. (SEGREDO DE JUSTIÇA) (Apelação Cível N. 70005798004, Sétima Câmara Cível, Tribunal de Justiça do RS, Relator: Luiz Felipe Brasil Santos, Julgado em 09/04/2003). 
MORAES, Alexandre de. Direito constitucional. 20ª ed. São Paulo:Atlas, 2006. NORONHA, Carlos Silveira (Org.) As novas perspectivas do direito das sucessões: em tempos de modernidade e pós-modernidade. Porto Alegre: Sulina, 2011.

PONTES DE MIRANDA, Francisco Cavalcanti. Tratado de direito privado. Parte Especial. Tomo LVIII. Direito das sucessões: Sucessão testamentária. Disposiçõestestamentárias em geral. Formas ordinárias do testamento. Atualizado por Vilson Rodrigues Alves. Campinas: Bookseller, 2009.

RODRIGUES, Elza de Faria. Testamentos: teoria e prática. Belo Horizonte: Del Rey, 2011.

RODRIGUES, Silvio. Direito civil. V.7. Direito das sucessões. 17. ed. São Paulo: Saraiva, 1985.
ROSADO DE AGUIAR JR., Ministro Ruy (Org.). Jornada de Direito Civil. Brasília: CJF, 2007. Disponível em <http://columbo2. c j f.j us.br/portal/publicacao/download.wsp?tmp.arquivo=1296>. Acesso em: 7 jun. 2012.

VELOSO, Zeno. Comentários ao Código Civil: parte especial: direito das sucessões, v. 21 (arts. 1.857 a 2.027). AZEVEDO, Antônio Junqueira de (Coord.). São Paulo: Saraiva: 2003.

VENOSA, Sílvio de Salvo. Direito civil: direito das sucessões. V.7. 5. ed. São Paulo: Atlas, 2005.

WALD, Arnoldo. Direito das sucessões. Curso de Direito Civil Brasileiro. V. V.11. ed. São Paulo: Editora Revista dos Tribunais, 1997. 